\title{
DEVOTION TO COMMUNITIES "POSYANDU" GROUP OF PREGNANT MOTHER THROUGH INTRODUCTION TO HAZARD SIGNS IN PREGNANCY SUB-DISTRICT MEDAN SUNGGAL
}

\author{
Bina Melvia Girsang ${ }^{1 \mathrm{a}}$, Evi Indriani $\mathrm{Karo}^{2}$, Farida Linda Sari $^{1}$ \\ ${ }^{1 a}$ Maternity and Child Department, Faculty of Nursing \\ binamelvia@usu.ac.id \\ ${ }^{1}$ Maternity and Child Department, Faculty of Nursing \\ farida.linda@ymail.com \\ ${ }^{2}$ Maternity and Child Department, Faculty of Nursing \\ evi_indri@yahoo.com
}

\begin{abstract}
Recognition of pregnancy danger plays an important role in preventing and reducing maternal mortality. Pregnant women can identify the danger signs of pregnancy. Therefore, the danger signs during pregnancy need to be known by pregnant women, especially those that threaten the health of the mother and the fetus who are pregnant. The minimum needs to be known by pregnant women in the community to recognize pregnancy danger signs, namely bleeding out of birth canal, excessive nausea, preeclampsia and eclampsia, premature rupture of membranes, and fetal movements that are not felt. Medan Sunggal Health Center is one of the village areas assisted by the USU Nursing Faculty. Based on the results of previous studies of pregnant women, it was found that there were still many pregnant women who did not know about the signs and dangers during pregnancy. The main cause is the limited knowledge of mothers about the signs and dangers of pregnancy and the mother's skills to overcome the lack of information about the signs and dangers of pregnancy. Posyandu cadres who have played an active role have been felt to be weak in providing education about information on signs and harms of pregnancy. Posyandu cadres have the potential for their role as agents of change. Therefore to overcome the problem of lack of information about the signs and dangers of pregnancy, it is necessary to improve the method of delivering information on signs and dangers of pregnancy, by involving several parties who can later collaborate in dealing with information problems for pregnant women, involving KIA officers from Sunggal Health Center, cadres , and invite pregnant women.
\end{abstract}

Keywords : information, pregnancy, danger sign 
Girsang, BM. et al. Devotion To Communities "Posyandu" Group Of Pregnant Mother Through Introduction To....

\section{INTRODUCTION}

The danger signs of pregnancy are signs that indicate a danger that can occur during pregnancy / antenatal period, which if not reported or undetectable can cause death. Recognition of pregnancy danger plays an important role in preventing and reducing maternal mortality. Pregnant women can identify the danger signs of pregnancy through the Maternal and Child Health (KIA) book, which they have had since pregnancy (Pusdiknakes, 2003). Complications of pregnancy, childbirth and childbirth are important health problems, if not addressed it will cause a high maternal mortality rate. The death of a mother in the process of reproduction is a worrying tragedy. The existence of a mother is a milestone for achieving a prosperous family and the death of a mother is a disaster for her family. The social and economic impacts of this event can be very large, both for families, communities and the workforce.

One of the causes of the risk of maternal death and illness is one that is not detected by danger signs during pregnancy due to irregular ANC visits (Komalasari, 2010). Therefore, danger signs during pregnancy need to be known by pregnant women especially those that threaten maternal and fetal health. the amount that is needed by pregnant women in the community to recognize the danger signs of pregnancy, namely bleeding from the birth canal, nausea, excessive vomiting, preeclampsia and eclampsia, premature rupture of the membranes, and undetected fetal movements (Salamah 2006, p.98).

The research conducted by Mahardani at the Sawan I Bali Health Center (2011) showed that $54.2 \%$ of pregnant women had insufficient knowledge in early detection of the danger signs of pregnancy. The Lestari (2012) study in Ambarawa said that $61.2 \%$ of pregnant women were categorized as lacking in utilizing MCH books to obtain information about the danger signs of pregnancy. The danger signs of pregnancy are signs that indicate a danger that can occur during pregnancy / antenatal period, which if not reported or undetectable can cause death. Recognition of pregnancy danger plays an important role in preventing and reducing maternal mortality.
Pregnant women can identify the danger signs of pregnancy through the Maternal and Child Health (KIA) book, which they have had since pregnancy (Pusdiknakes, 2003). Complications of pregnancy, childbirth and childbirth are important health problems, if not addressed it will cause a high maternal mortality rate. The death of a mother in the process of reproduction is a worrying tragedy. The existence of a mother is a milestone for achieving a prosperous family and the death of a mother is a disaster for her family. The social and economic impacts of this event can be very large, both for families, communities and the workforce.

\section{METHOD OF ACTIVITY}

The methods of assistance included lectures, discussions, training, demonstrations, mentoring, and program evaluation. Lectures, discussions, demonstrations and training were conducted to increase the knowledge about product diversification. Further assistance was done for all the discussions that had been given. To measure the success of the program, the team conducted an evaluation from the beginning until the end of the program.

\section{RESULT AND DISCUSION}

The number of participants invited to the event was 27 people, consisting of 18 pregnant women, 6 posyandu cadres, and 2 Sunggal Puskesmas officers. The enthusiasm of the participants in the counseling activity on pregnancy signs was extraordinary. Most of the participants who were pregnant women. So this participant is expected to also be able to apply it when at home, and provide knowledge and motivation they get to their pregnant colleagues so that they can undergo a healthy pregnancy. 
Girsang, BM. et al. Devotion To Communities “Posyandu” Group Of Pregnant Mother Through Introduction To....

Table 1

Frequency Distribution of Characteristics of Pregnant Women

$$
\mathrm{N}=18
$$

Characteristic

Frequancy

Persentage (\%)

\begin{tabular}{|c|c|c|}
\hline \multicolumn{3}{|l|}{ Kelompok Trimester } \\
\hline Trimester I & 1 & 5,5 \\
\hline Trimester II & 5 & 27,8 \\
\hline \multirow[t]{2}{*}{ Trimester III } & 12 & 66,7 \\
\hline & & $100 \%$ \\
\hline \multicolumn{3}{|l|}{ Age } \\
\hline 20-30 years old & 11 & 61,1 \\
\hline $31-40$ years old & 6 & 33,3 \\
\hline \multirow[t]{2}{*}{$>40$ years old } & 1 & 5,5 \\
\hline & & 100 \\
\hline \multicolumn{3}{|l|}{ Parity } \\
\hline Primigravida & 7 & 38,8 \\
\hline Secundigravida & 2 & 11,1 \\
\hline Multigravida & 6 & 33,3 \\
\hline \multirow[t]{2}{*}{ Grandemultigravida } & 3 & 16,6 \\
\hline & & 100 \\
\hline \multicolumn{3}{|l|}{ History of abortion } \\
\hline Yes & 2 & 11,1 \\
\hline No & 16 & 88,8 \\
\hline
\end{tabular}


Girsang, BM. et al. Devotion To Communities "Posyandu” Group Of Pregnant Mother Through Introduction To....

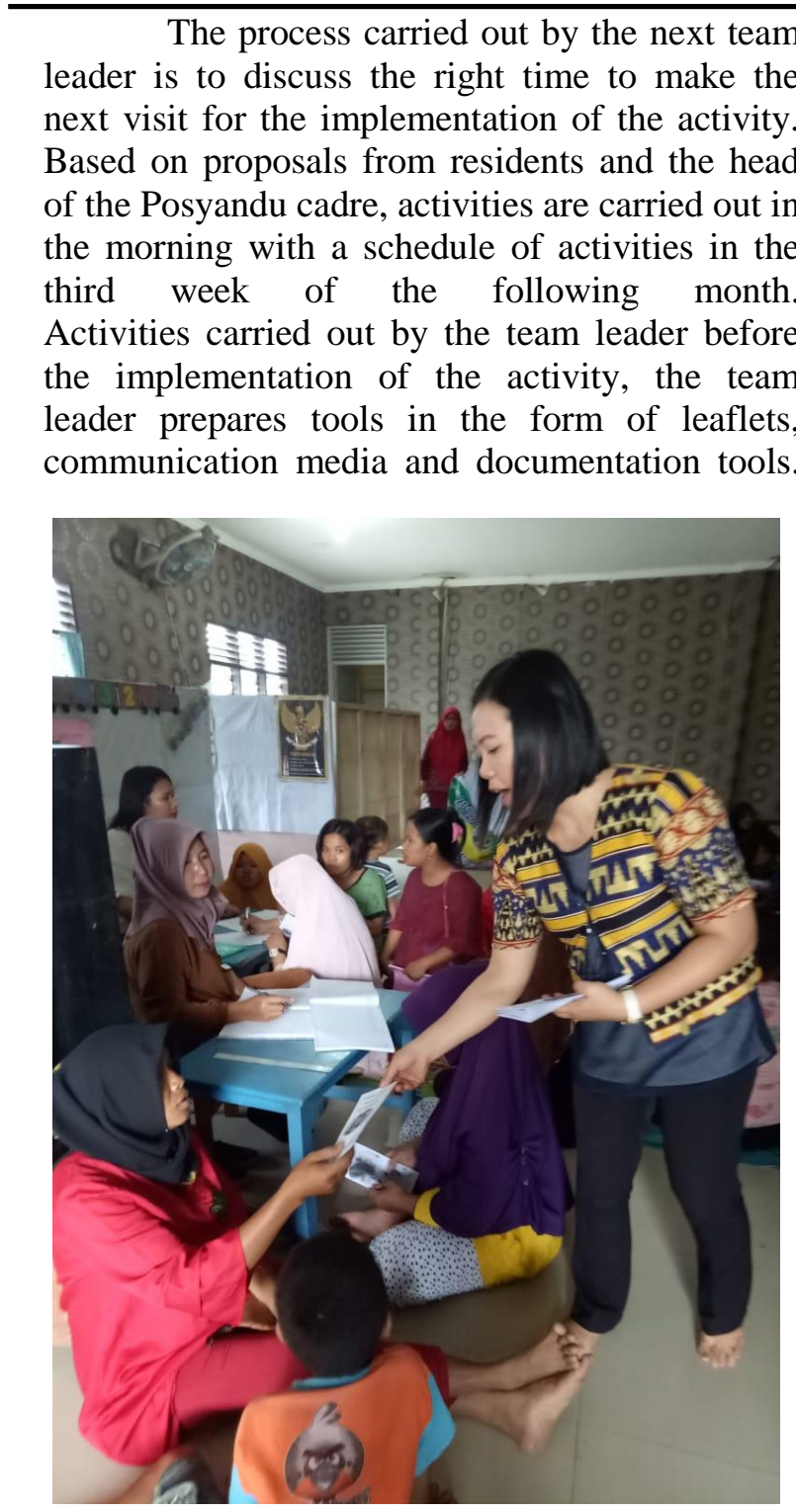

$\begin{array}{ccr}\text { Presenters prepare } & \text { material and } & \text { provide } \\ \text { counseling } & \text { to } & \text { mothers. } \\ \text { Pregnancy } & \text { awareness } & \text { counseling }\end{array}$
activities for pregnant women were carried out on Wednesday, September 19, 2018 at the Medan Sunggal village office at 09.00 WIB. The counseling participants were present before 09.00 WIB. Arriving at the location, we met with the mothers, and a group of posyandu cadres while distributing leaflets to the counseling participants, puskesmas officers and posyandu cadres.

Figure 1. Distribution of Leaflets from Presenters

When the activity will begin, the Presenter first provides direction to pregnant women about the benefits and objectives of counseling about the signs and dangers of pregnancy for pregnant women. 
Girsang, BM. et al. Devotion To Communities “Posyandu” Group Of Pregnant Mother Through Introduction To....
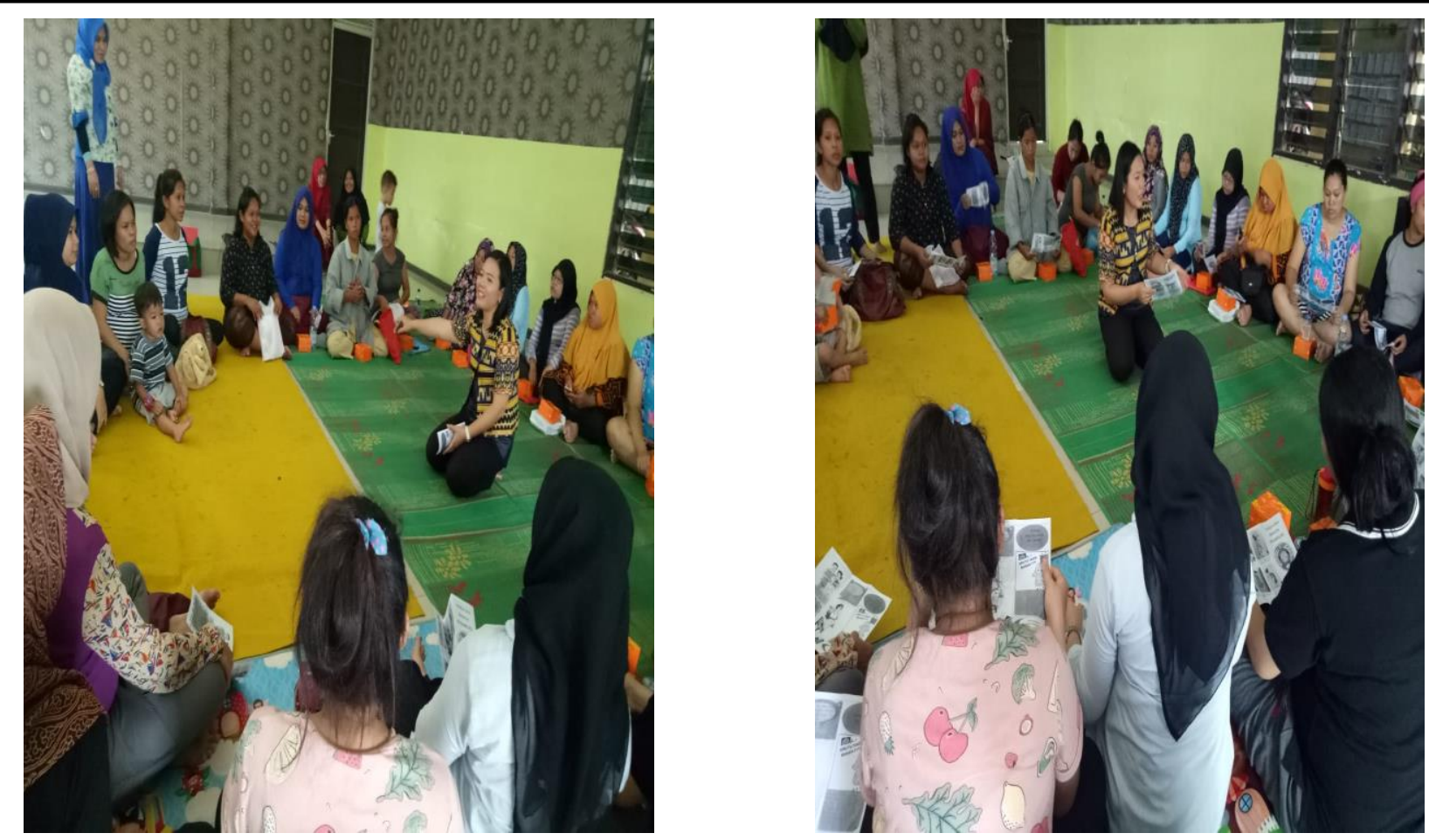

Figure 2. Extension counseling stage
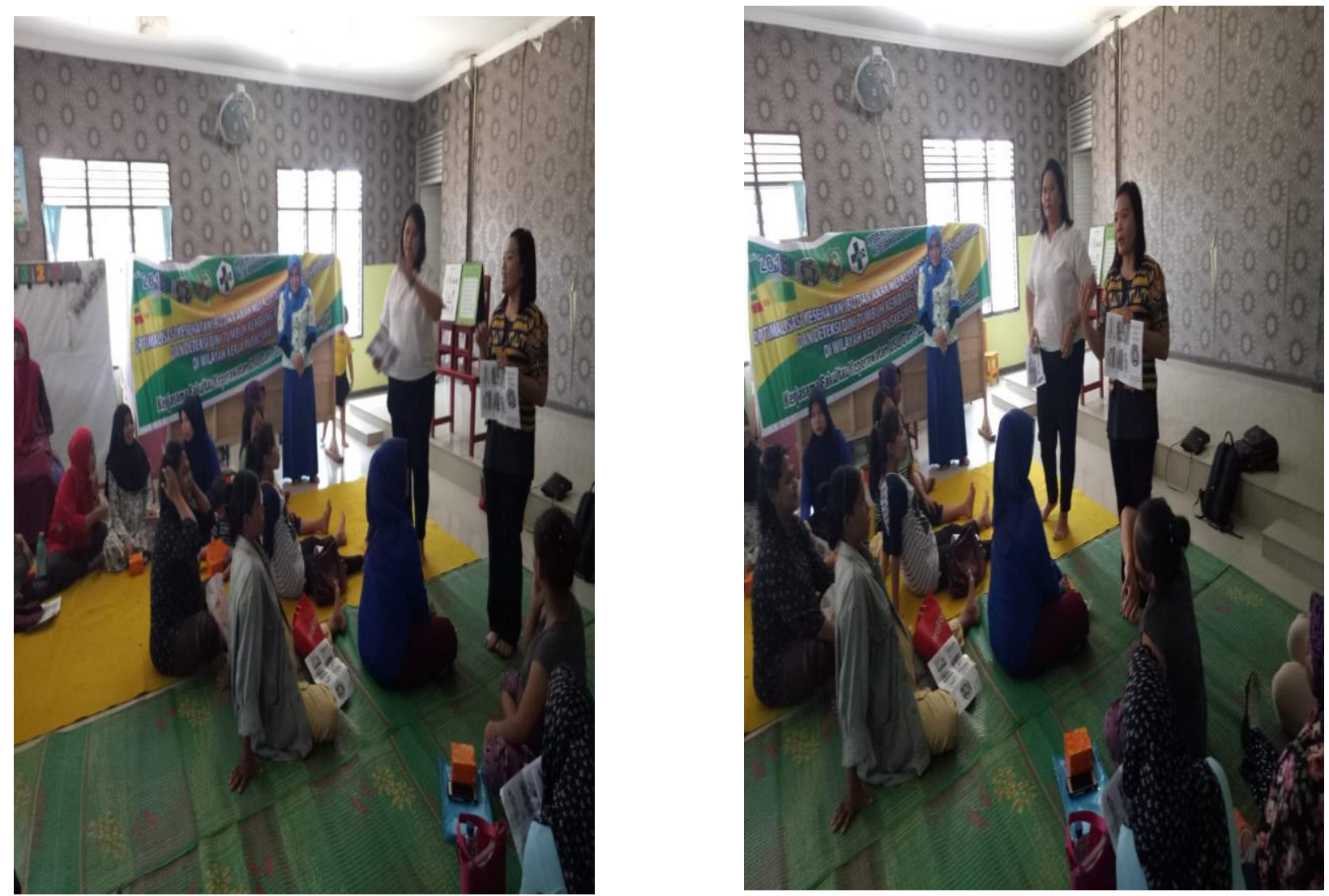

Figure 3. Implementation of Guidance Signs and Pregnancy Dangers 


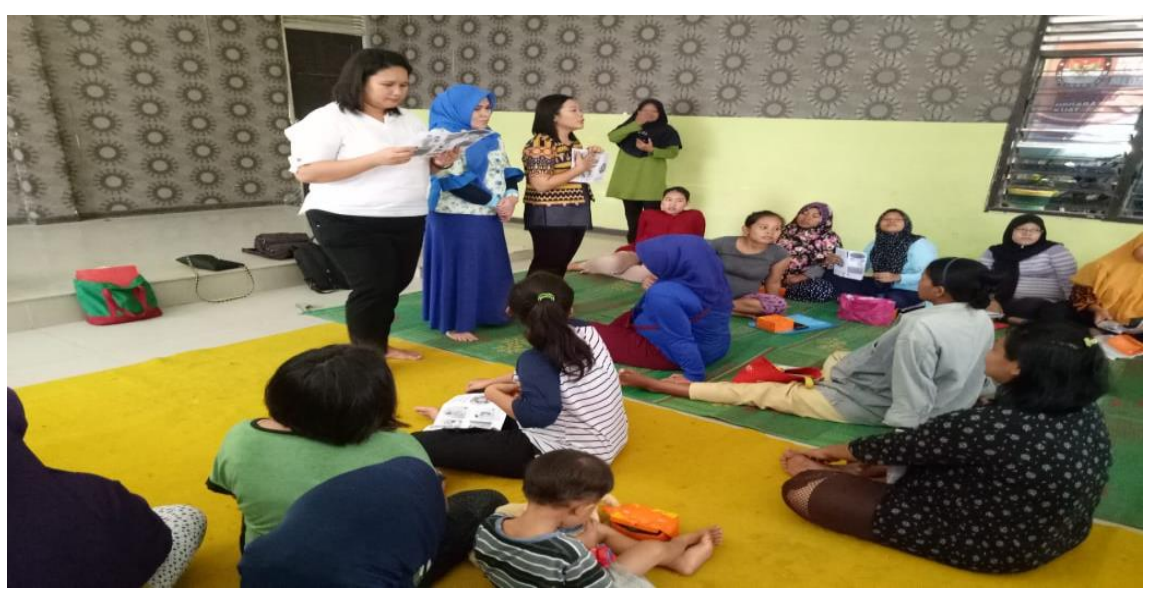

Figure 4. Termination of Extension Activities

Hazard detection and pregnancy complications are one of the efforts made in antenatal care given to pregnant women from conception to the onset of labor. The aim is to monitor the development of pregnancy in improving maternal health and normal fetal development. Screening to predict an illness, therefore we can find out those who will experience danger in their pregnancy. By detecting early illness can be distinguished pregnant women who will experience and who have experienced complications. Antenatal services aim to provide quality antenatal care and early detection of complications as early as possible

\section{CONCLUSION}

The group of pregnant women is very enthusiastic to participate in counseling activities and this is a strength map to empower women empowering in community groups, especially in conducting management to prevent maternal and fetal deaths during pregnancy and to support the welfare of the mother and fetus during pregnancy. Dissemination of health information about signs and dangers during pregnancy is very much needed and is expected to be facilitated by local health workers. Through this activity, it is expected that the success of the welfare of the mother and fetus during pregnancy can be realized, where there is still very little policy support in the empowerment program for pregnant women. This will also help the mother to make decisions for health care during pregnancy and her baby. Maternal and fetal health services are urgently needed by the community because of inadequate services and facilities, and minimal human resources in the Sunggal neighborhood, so it is strongly recommended that proactive maternal health services and attention from various parties be needed to improve health to reduce maternal mortality and fetus. 
Girsang, BM. et al. Devotion To Communities "Posyandu” Group Of Pregnant Mother Through Introduction To....

\section{ACKNOWLEDGEMENT}

We would like to express our gratitude and appreciation to all of the parties involved in this project, especially to the Ministry of Research, Technology and Higher Education that made this project possible. We also would like to express our gratitude to the LPPM of University of Sumatera Utara which has provided guidance and motivation to our team until the very end of this project

\section{REFERENCES}

Asrinah, dkk. 2010. Asuhan Kebidanan Masa Kehamilan. Yogyakarta: Graha Ilmu

Departemen Kesehatan RI. 2001. Buku Pedoman Pengenalan Tanda-tanda bahaya Kehamilan, Persalinan, dan Nifas. Jakarta

Kumalasari, I \& Iwan, A. 2012. Kesehatan reproduksi untuk mahasiswa kebidanan dan keperawatan. Salemba Medika. Jakarta

Kusmiyati Y, Heni P.W dan Sujiyatini. 2009. Perawatan Ibu Hamil (Asuhan Ibu Hamil). Cetakan Kelima, Yogyakarta: Fitramaya

Paramita, Boni Lestari.(2012). Hubungan Antara Pemanfaatan Buku KIA Dengan Tingkat Pengetahuan Dan Sikap Ibu Hamil Tentang Tanda-Tanda Bahaya Kehamilan Di BPM Ny. E Kecamatan Ambarawa.

Masjoer, A dkk. 2001. Kelainan pada Persalinan dalam Kapita Selekta Kedokteran3th ed Jilid pertama. Jakarta: Media Aesculapius FKUI

Manuaba, I, A, Bagus, G, F, I \& Bagus, G, M, I. 2009. Buku Ajar Patologi Obstetri. EGC. Jakarta

Mandriwati. 2008. Penuntun Belajar Asuhan Kebidanan Ibu Hamil. EGC: Jakarta Mahardani. 2011. Faktor-faktor Yang
Berhubungan dengan Pengetahuan Ibu Hamil dalam Deteksi Dini Tanda Bahaya Kehamilan di wilayah Kerja Puskesmas Sawan I Kecamatan Sawan Kabupaten Buleleng Provinsi Bali. Skripsi : FKM UI

Mangkuji, Betty. 2013. Asuhan Kebidanan 7 Langkah SOAP. Jakarta : EGC

McCarthy J, Maine D. 1992. A framework for analyzing the determinants of maternal mortality. Stud Fam Plann. 1992 Jan Feb;23(1):23-33

Notoatmodjo, S .2007. Promosi Kesehatan dan Perilaku Kesehatan. Rineka Cipta. Jakarta

Poehjati P, dkk. 2003. Paket Kehamilan dan Persalinan Aman Dalam Akselerasi Penurunan AKI, Majalah Kedokteran Indonesia, 53 (3) : 116-119, Jakarta Prawirohardjo, S. 2008. Ilmu Kebidanan. Bina Pustaka Sarwono Prawiroharjo. Edisi Keempat. Jakarta

PUSDIKNASKES, WHO dan JHPIEGO, 2003. Asuhan Antenatal dan Asuhan Intrapartum, Jakarta.

Saifuddin, A. B. 2008. Buku Acuan Nasional Pelayanan Kesehatan Maternal dan

Neonatal. Jakarta: PT Bina Pustaka Sarwono Prawirohardjo

Salamah. 2005, Asuhan Kebidanan Antenatal, Jakarta: $E G C$.

WHO. 2007. Dibalik Angka Pengkajian Kematian Maternal dan Komplikasi untuk Mendapatkan Kehamilan yang lebih Aman. Jakarta.

Wiknjosastro, H. 1999. Ilmu Kebidanan.Jakarta: PT Bina Pustaka

http://repository.usu.ac.id/bitstream/12345678 9/16931/4/Chapter\%20II.pdf

http://repository.usu.ac.id/bitstream/12345678 9/27265/5/Chapter\%20I.pdf 